УДК 94(477.83)»1941/44»

DOI 10.24919/2519-058x.4.111466

Василь ІЛьнИЦькиЙ, orcid.org/0000-0002-4969-052X доктор історичних наук,

професор кафедри історії України Дрогобииького державного педагогічного університету імені Івана Франка (Украӥна, Дрогобич) vilnickiy@gmail.com

Микола ГАЛІВ, кандидат педагогічних наук, дочент, доиент кафедри історії України Дрогобицького державного педагогічного університету імені Івана Франка (Україна, Дрогобич)halivm@yahoo.com

\title{
ДОКУМЕНТ РАДЯНСЬКИХ ОРГАНІВ ДЕРЖБЕЗПЕКИ ПРО ДІЯЛЬНІСТЬ ОСЕРЕДКУ НАЦИСТСЬКОЇ СД (СЛУЖБИ БЕЗПЕКИ) В ДРОГОБИЧІ (1941 - 1944 рр.) ${ }^{1}$
}

У статті публікується невідомий документ про функиіонування осередку начистської Служби безпеки у Дрогобичі (1941 - 1944). Коротко описано структуру, керівний кадровий склад дрогобииької СД. Окреслено час існування осередку СД в Дрогобичі, місие його перебування. Виокремлено функиії СД та масштаби діяльності начистської розвідки і контррозвідки. На основі досліджуваного документа розглянуто та сформовано певне уявлення про «форми» роботи органів МДБ на Дрогобиччині. Зокрема способи вербування агентурно-інформативного апарату.

Ключові слова: Дрогобич, СД, Зіпо, МДБ, агентура.

Jim. 15.

Vasyl ILNYTSKYI, PhD hab. (History), Professor of Department of Ukraine's History of Drohobych Ivan Franko State Pedagogical University (Ukraine,Drohobych)vilnickiy@gmail.com

Mykola HALIV,

PhD (Education), Assistant Professor of Ukraine's History Department of Drohobych Ivan Franko State Pedagogical University (Ukraine,Drohobych)halivm@yahoo.com

\section{THE DOCUMENT OF THE SOVIET STATE SECURITY BODIES ON THE ACTIVITY OF THE NAZI SECURITY SERVICE CENTRE IN DROHOBYCH (1941 - 1944)}

The article presents a hitherto unknown document about the functioning of a Nazi Security Service centre in Drohobych (1941 - 1944). The period from July 1, 1941 to August 6, 1944, during which Drohobych was under the Nazi occupation, is not yet sufficiently studied by the scientists and local country historians. First of all, it concerns the materials about the German state bodies, of which almost no archive materials survived.That is why the aim of the article is to supplement the existinf information on the activity of the Nazi State Security centre (SSC) in Drohobych in 1941 - 1944. The structure and managing cadre staff of Drohobych Nazi SSC is described in brief. The chronological period of functioning of the aforementioned SSC in Drohobych and its location. Its functions and the activity scale of the nazi secret service and counterespionage are singled out.On the basis of the document under consideration a certain comprehention of the the "forms» of work of the curity Ministry in Drohobych land, in particular, the ways of recruiting of its secret-service and informative apparatus.

Key words: Drohobych, Secret Service, Ministry of State Security.

Ref. 15.

${ }^{1}$ Публікація містить результати досліджень, проведених при грантовій підтримці Держаного фонду фундаментальних досліджень за конкурсним проектом договір Ф77/80-2017 від 31.08.2017 р. 
Василий ИЛЬНИЦКИЙ,

доктор исторических наук, профессор кафедры истории Украины Дрогобычского государственного педагогическогоуниверситета имени Ивана Франко (Украина, Дрогобич) vilnickiy@gmail.com

Николай ГАЛИВ, кандидат педагогических наук, дочент, доцент кафедры истории Украины Дрогобычского государственного педагогического университета имени Ивана Франко (Украина, Дрогобыч) halivm@yahoo.com

\section{ДОКУМЕНТ СОВЕТСКИЕ ОРГАНЫ ГОСБЕЗОПАСНОСТИ О ДЕЯТЕЛЬНОСТИ ОЧАГЕ НАЦИСТСКИМ СД (СЛУЖБЫ БЕЗОПАСНОСТИ) В ДРОГОБЫЧЕ (1941 - 1944 ГГ.)}

В статье публикуется неизвестный документ о функиионировании организации нацистской Службыл безопасности в Дрогобыче (1941 - 1944). Коротко описана структура, руководящий кадровый состав дрогобычской СД. Определены время существования организации СД в Дрогобыче, место его нахождения. Выделены функции СД и масштабы деятельности нацистской разведки и контрразведки. На основе исследуемого документа рассмотрены и сформированы определенное представление о «формы» работы органов МГБ на Дрогобиччини. В частности способы привлечения агентурно-информативного аппарата.

Ключевые слова: Дрогобыч, СД, Зипо, МГБ, агентура.

Лиm. 15.

Постановка проблеми. Період перебування міста Дрогобич під нацистською окупацією (1 липня 1941 - 6 серпня 1944 рр.) недостатньо вивчений науковцями, краєзнавцями. Особливо це твердження стосується німецьких органів влади, про діяльність яких майже не збереглося архівних матеріалів.

Аналіз джерел та останніх досліджень. Діяльність німецьких органів влади реконструюється і конструюється здебільшого на основі спогадів мешканців міста. Українська мемуаристика щодо цього питання найбільш скупчено репрезентована в чотирьох томах збірника «Дрогобиччина - земля Івана Франка» [14]. Спогади дрогобицьких поляків і євреїв часто з'являються на сторінках вроцлавського видання «Ziemia Drohobycka». Чимало мемуаристики було зібрано, опрацьовано і нерідко тенденційно інтерпретовано в праці письменника В. Будзинського [15]. Потрібно також відзначити спогади осіб, які відвідували Дрогобич у ці важкі роки. 3-поміж них можемо назвати документальні спогади голови Українського крайового комітету, а згодом заступника голови УЦК К. Паньківського [11], деяких пресових матеріалів (газети «Вільне (Дрогобицьке) слово», «Голос Підкарпаття»).

Чимало інформації про діяльність органів СД і Зіпо, їх окремих службовців зібрав та оприлюднив В. Будзинський у книзі «Miasto Schulza». У ній він, зокрема, оперував і витягами зі щоденника дрогобицького гестапівця Ф. Ландау, які зараз можна знайти навіть в інтернеті. Для висвітлення питання функціонування нацистських органів безпеки у Дрогобичі важливою є джерелознавча публікація В. Ільницького [8].

Особливо мало джерельних матеріалів маємо про діяльність «силових» органів влади в Дрогобичі: військово-польової комендатури, органів СД і Зіпо, шуцполіції, української допоміжної поліції. Щоправда, у Державному архіві Львівської області ми виявили низку фондів з різною кількістю справ, що стосуються цих структур. Для прикладу, там зберігаються усього три справи, що висвітлюють деякі заходи комендатури $[4 ; 5 ; 6]$. Більша кількість справ, які наразі нами опрацьовуються, стосується шуцполіції та української поліції в Дрогобичі. Зовсім мало інформації збереглося про діяльність Дрогобицького осередку СД-Зіпо. Попри те, що в довідкових виданнях засвідчена наявність трьох справ у фонді «Дрогобицьке відділення поліції і служби безпеки» Державного архіву Львівської області $[1,354]$, там насправді зберігається лише одна справа, яка частково проливає світло на використання окупаційними властями євреїв Дрогобицької округи як трудового ресурсу [7].

Мета статті - доповнити наявну інформацію про діяльність осередку нацистської СД (служби безпеки) в Дрогобичі (1941 - 1944 р.).

Виклад основного матеріалу. СД - це служба безпеки, а Зіхергейтполіцай (Зіпо) - поліція безпеки. 31939 р. ці спеціальні служби Третього Рейху були об'єднані під егідою Генерального управ- 
ління імперської безпеки (РСXА). Зокрема, СД складало III (SD-Inland, внутрішня СД) i VI (SD-Aucland, СД-Закордон) управління РСХА. Органи СД займалися розвідкою та таємними операціями. Вони тісно співпрацювали з Зіпо, яка, власне, складалася з двох структур: таємної поліції - гестапо та кримінальної поліції - кріпо (керівники гестапо і кріпо були заступниками шефа Зіпо). На місцевому рівні це проявлялося, зокрема, в тому, що в апараті СД і Зіпо працювали одні й ті ж функціонери. Для прикладу, осередок СД і Зіпо очолювала одна й та ж людина [13, 7-8, 10, 21-22, 59-60].

У липні - вересні 1941 р., коли активно формувалася мережа органів СД і Зіпо в окупованій нацистами Східній Галичині, Дрогобич став одним із чотирьох (потім утворено ще два) осередків цих структур у дистрикті «Галичина». Дрогобицька команда СД і Зіпо контролювала ще й Самбірську та Стрийську округи [10, 399].

Власне, завдяки В. Будзинському знаємо, що формування структур СД і Зіпо почалося в Дрогобичі ще 7 липня 1941 р., після приїзду сюди айнзацкоманди «Радом'яни» (з м. Радом) у складі: Ніколас Толе, Вальтер Кучман, Йозеф Габріель, Рудольф Сокол, Вернер Міхаеліс, Фелікс Ландау, Франц Вензель, Фрідріх Денг, Віллі Морлок, Карл Гюнтер, Гельмут Краус, Фердинанд Камеpep, Філіп Ебенрехт $[15,416]$. У «Нарисах з історії Дрогобича...», також спираючись на дані В. Будзинського, вказано, що шефом СД-Зіпо-Дрогобич від липня 1941 р. був Н. Толе 2 , а $з$ жовтня Ф. Вензель. Шефом гестапо в Дрогобичі від липня 1941 р. був В. Кучман, з березня 1942 р. - Гейдук, а опісля - Ганс Блок (червень 1942 - серпень 1944 р.) [10, 194].

Усі ці відомості про відділ СД в Дрогобичі доповнює, а подекуди й уточнює та коригує віднайдений в Галузевому державному архіві Служби безпеки України російськомовний документ, який власне публікуємо. Документ під заголовком «Довідка по літерній справі на німецький контррозвідувальний орган «СД» Дрогобицької округи» було позначено грифом «Цілком таємно» й датовано 5 березня 1947 р. Його уклав заступник начальника 2-го відділу Управління Міністерства держбезпеки УРСР в Дрогобицькій області лейтенант О. Рудь, погодив виконувач обов'язків цього відділу майор Пронін і затвердив начальник Дрогобицького УМДБ полковник В. Майструк.

«Довідка...» окреслює час існування осередку СД в Дрогобичі, місце його перебування (вул. Міцкевича, $13^{3}$ - зараз вул. Т. Шевченка), представників керівництва. Цікаво, що за інформацією радянських спецслужб, Н. Толе керував Дрогобицьким СД аж до серпня 1942 р., хоча за іншими даними його уже в жовтні 1941 р. заступив Ф. Вензель (Венцель) [14, 197, 419]4․ Ганс Блок (у «Довідці...»-Йоганс), за твердженням В. Будзинського, був шефом гестапо у Дрогобичі від червня 1942 до серпня 1944 рр. Водночас, наводячи інформацію «з інших джерел», польський письменник говорить, що Г. Блок з червня 1942 р. став «шефом гарнізону СС і поліції / гестапо в Дрогобичі» [14, 193, 419]. Під «гарнізоном СС», скоріше, мається на увазі дрогобицький осередок СД-Зіпо.

\footnotetext{
${ }^{2}$ Російський німець Ніколас Толе згадується у спогадах А. Гладиловича (див.: Гладилович А. «Кличе Україна, наша Батьківщина» // Дрогобиччина - земля Іван Франка: Збірник географічних, історичних, етнографічно-побутових матеріалів та мемуарів. - Т. 4. - Дрогобич: «Відродження», 1997. - С. 362 - 371.). У жовтні 1942 р. його було переведено на роботу до Львова, де він зайняв посаду господарського референта СД дистрикту «Галичина». Про Н. Толе є згадки в спогадах К. Паньківського (див.: Паньківський К. Роки німецької окупації. - Нью-Йорк - Торонто, 1965. - С. 90-91). Зокрема, К. Паньківський так охарактеризував цього нацистського чиновника: «Толле, родом з Владивостока, говорив по російськи і як усі російські німці, мав великий респект до великої Росії і при всій своїй ввічливості до нас (представників української громадськості. - Авт.), мало розуміння для справ «малого простору». Знаменито підходив би в сьогоднішній час до товариства американців, захоплених великою Росією» (Там само. - С. 91).

${ }^{3}$ На вулиці А. Міцкевича, 13 (Гауптштрассе, 13), тобто у віллі Р. Яроша знаходилося казино для гестапівців (див.: Budzyński W. Miasto Schulza...- S. 192), де також влаштовано декілька кабінетів для функціонерів гестапо. У своїх спогадах В. Яців вказував адресу «квартири Гестапо»- вул. А. Міцкевича, 15 (див.: Яців В. Дрогобич - місто нафтового басейну ... - С. 95). Про це говорив і В. Будзинський, зазначаючи, що шеф гестапо Й. Блок «урядує при вул. Гауптштрассе, № 15» (Budzyński W. Miasto Schulza...-S. 193). А. Гладилович писав: «Велику нову будівлю на розі вулиці Міцкевича й Самбірської зайняло гестапо Дрогобицької округи і почало свою чорну справу» (Гладилович А. «Кличе Україна, наша Батьківщина» ... - С. 367). Йдеться про будинок на розі сучасних вулиць Т. Шевченка та Січових Стрільців, навпроти міської поліклініки. Кріпо і СД займали ще два будинки на вулиці Міцкевича-Гауптштрассе.

${ }^{4}$ Про Вензеля, як коменданта Сіпо в Дрогобичі, згадує дрогобичанин А. Шраєр (Tam że. - S. 197).
} 
На жаль, у документі нічого не згадується про загибель 30 листопада 1943 р. у бою під Недільною із загонами Української народної самооборони гестапівця з Дрогобича обершарфюрера СД Лявфмана $[12,142 ; 9,71]$. В. Яців зауважив, що Лявфман був «комендантом обласного (окружного. - Авт.) Гестапо» $[14,96]$. Це суперечить твердженню З. Будзинського про Г. Блока, як на той час керівника гестапо у Дрогобичі, але відповідає іншим вказівкам «Довідки...», згідно з якими Г. Блок усе ж від весни 1943 р. очолив місцеве СД-Зіпо. Тож тоді Г. Блок цілком міг звільнити вакансію начальника гестапо для Лявфмана, котрий відтепер, став заступником шефа СД-Зіпо.

Зауважимо, що «Довідка...» спростовує «правдоподібне» припущення З. Будзинського про загибель Г. Блока у 1944 р. [15, 193]. Його, виявляється, було заарештовано на початку 1947 р. у Відні. Саме до Відня його дружина вивозила награбоване Г. Блоком добро дрогобицьких євреїв упродовж $1942-1944$ pp. [15, 192].

Надзвичайно важливою є вказівка «Довідки...» на структуру Дрогобицького СД-Зіпо. Вона складалася з 10 відділів, очолюваних поліціянтами, причому траплялися випадки, мабуть, з огляду на брак кадрів, коли одна людина очолювала два відділи. Відзначимо, що радянські спецслужби на 1947 р. не мали повної інформації про функціонерів СД-Зіпо. Так, керівником відділу у справах євреїв вони зафіксували Й. Габріеля. Проте значно триваліший період часу цим відділом керував Ф. Ландау - майже два роки. Лише у травні 1943 р. Г. Блок зняв Ф. Ландау з цього уряду, призначивши на його місце Й. Габріеля [15, 188-190]. Гестапівця К. Гюнтера, який 19 листопада 1942 р. застрелив Бруно Шульца [15, 192, 421; 16, 37-44], в «Довідці...» названо Гінтером. 3 іншого боку, у «Довідці...» зафіксовано низку прізвищ членів дрогобицького СД, раніше ніде не згадуваних (Хіртшульц, Бер, Шольтен). 3 документа виливає, що працівникам Дрогобицького Управління МДБ на 1947 р. були відомі, щонайменше 25 функціонерів СД Дрогобича, з них 6 заарештували (на жаль, не вказано кого) і 19 оголосили у розшук.

Викликає зацікавлення і перелік підпорядкованих шефу СД структур, зокрема, згадка про українську поліцію та українську допоміжну поліцію. На нашу думку, йшлося не про цілком різні структури. Відомо, що з серпня 1941 р. в галицькому дистрикті за тим же зразком, що і в Краківському та Люблінському дистриктах Генеральної Губернії, було сформовано Українську допоміжну поліцію (Ukrainische Hilfpolizei). Офіційно вона підпорядковувалася керівництву поліції порядку (Орпо), а насправді кожному німцеві в уніформі. Цілком можливо, що саме ії в «Довідці... . названо просто «Українською поліцією», а під «Українською допоміжною поліцією» малися на увазі або ж новобранці, або ж українське допоміжне формування для шуцполіції. Такі українські «шуми» носили білі пов'язки на рукавах. Зауважимо, що, згідно з даними польського підпілля, на 1 січня 1943 р., в Дрогобичі німецькі силові структури репрезентували: гарнізон вермахту - 308 вояків, Зіпо - 72 особи, жандармерія - 76 вояків (у листопаді 1941 р. іiї очолював лейтенант Венте [2, 4]), шуцполіція - 124 особи, українська поліція 146 вояків, «українці з білими пов'язками» - 139 чол., веркшуц - 8 вояків, баншуц - 13 осіб [15, 248]. Як бачимо, аківці також розрізняли «українську поліцію» $\mathrm{i}$ «українців з білими пов'язками».

Остання частина документа присвячена функціям СД і непрямо свідчить про масштаби діяльності нацистської розвідки і контррозвідки. Зокрема, лише місцевих агентів СД радянські спецслужби заарештували начебто 114 осіб, ще 9 подали до розшуку. Крім того, 39 людей «розроблялися» (вивчалися або й уже використовувалися в агентурній роботі) працівниками МДБ. Загалом, згідно з «Довідкою...», було виявлено агентурну сітку СД на Дрогобиччині чисельністю 162 особи.

Звісно, можна сумніватися у цих числах, беручи до уваги «практику роботи» чекістів, які інколи просто виконували «план», дописуючи «провини» нерідко безневинним людям. Однак не слід забувати й слова К. Паньківського, котрий так говорив про агентуру СД у Львові та галицькому дистрикті загалом: «...СД мала широкі кола таємних штатних співробітників та - як я швидко завважив - ще більшу кількість мимовільних. Таємних ми не знали, а тільки могли щодо них здогадуватися. Мимовільних ми бачили в усіх урядах, але передовсім в СД, де тільки нам прийшлося бувати. Одну групу становили люди, що перебували два роки в старому ГГ (Генеральній Губернії. - Авт.) та тепер відвідували знайомих німецьких урядовців, щоб використати своє знайомство при отриманні «повірництва» якогось підприємства або торгівлі. Друга група це були вже наші галицькі громадяни, які приходили із проханнями у різних своїх дрібних справах, також і повірництва. Усі вони ставали при такій нагоді неоціненним джерелом інформації для досвідчених членів СД про наше життя, настрої, поведінку і за польських і за большевицьких часів, та вкінці за німців» $[11,89]$. 
Висновки. На завершення відзначимо, що досліджуваний документ дає можливість сформувати й певне уявлення про «форми» роботи органів МДБ на Дрогобиччині. По справі СД інформацію здобував «агентурно-осведомительный аппарат» у складі шести осіб, з них один агент та п’ять «осведомителей». Очевидно, працював «апарат» доволі успішно, раз результат їхньої роботи щодо виявлення колишніх агентів та резидентів СД помістився аж на 24 сторінках на яких містилася інформація на 162 особи. Прізвища та інші біографічні дані цих осіб автори з етичних міркувань не публікують.

Документ

«УТВЕРЖДАЮ»

НАЧАЛЬНИК УМГБ ДРОГОБЫЧКОЙ ОБЛАСТИ

Совершенно секретно

П О Л К О В Н И К

/МАЙСТРУК ${ }^{5}$ /

«__ м марта 1947 года.

\author{
СП Р А В K A \\ по литерному делу на немецкий контрразведывательный \\ орган «СД» Дрогобычского округа.
}

Агентурно-следственным путем установлено, что в период немецкой оккупации в гор. Дрогобыч с августа 1941 года по июль 1944 год дислоцировался контрразведывательный немецкий орган «СД» (Окружной отдел), который размещался по ул. Мицкевича в доме № 13.

${ }^{5}$ Майструк Володимир Федорович (27.11.1903, м. Проскурів (нині Хмельницький) - ?). Українець. Член партії (1928), на чекістській роботі з 1932 р. Освіта середня (Проскурівська трудова школа 1921 р., 1 курс Харківського інституту комуністичного просвітлення, 1932 р.). Заочно навчався на юридичному факультеті Львівського державного університету. Працював робочим по ремонту шосейних доріг м. Проскурів (1921 - 1923). Працював на різних підсобних роботах м. Проскурів Кам’янець-Подільської області (1923 1934). Червоноармієць музикальної команди 1 Червоно-Козачого полку (1924 - 1925). Червоноармієць 134 Придністровського полку м. Київ (1925 - 1927). Пропагандист пересувної партизанської школи окружного комітету КП(б)У м. Проскурів (1927 - 1928). Завідувач агітаційним відділом райкому КП(б)У м. Проскурів (1928 - 1929). Інструктор і завідувач партіним просвітленям культурно-пропагандистським відділом окружного комітету КП(б)У м. Проскурів (1929 - 1930). Завідувач агітаційно-масовим відділом Волковинецького райкому КП(б)У Кам'янець-Подільскої області (1930 - 1931). Завідувач культурно-пропагандистським відділом Деражнянського райкому КП(б)У Кам'янець-Подільської області (1931). Навчався в Центральній школі Об'єднаного державного політичного управління СРСР $(04.1932$ - 03.1933). Працює на різних посадах в органах Державного політичного управління - Народного комісаріату внутрішніх справ (НКВС) УРСР по Вінницькій області, лейтенант державної безпеки (03.1933 - 12.09.1940). У 1941 - 1943 рр. притягався до кримінальної відповідальності за вчинення безпідставних масових політичних репресій та фальсифікацію матеріалів слідства в Управлінні НКВС УРСР по Вінницькій області. Працює на різних посадах в органах НКВС - Народного комісаріату державної безпеки (НКДБ) УРСР по Ворошиловградській (нині Луганській) області, старший лейтенант державної безпеки (12.04.1941 - 15.05.1944). Заступник начальника Управління НКДБ УРСР по Тернопільській області (15.05.1944 - 09.10.1944). Начальник Управління НКДБ-МДБ УРСР по Дрогобицькій області, полковник державної безпеки з (09.10.1944 - 09.12.1948). В.о. начальника УНКДБ Тернопільської області. Начальник Управління МДБ УРСР по Львівській області (09.12.1948 - 09.06.1952). Начальник Управління Міністерства внутрішніх справ УРСР по Житомирській області (09.06.1952 -30.03.1953). Виконуючий обов'язків начальника Управління Міністерства внутрішніх справ (МВС) УРСР по Житомирській області (30.03.1953 - 16.04.1953). В розпорядженні МВС УРСР (16.04.1953 - 15.07.1953). Виконуючий обов'язків заступника начальника 4 Управління МВС УРСР (15.07.1953 - 01.03.1954). В розпорядженні МВС УРСР $з$ (01.03.1954). Член бюро Львівського обкому КП(б)У, депутата Львівської обласної Ради депутатів трудящих. Нагороджений: орденом «Червоного знамення», «Трудового Червоного знамення», «Вітчизняної війни 1 ступеня», «Червоної зірки» (12.05.1945), «Знак почоту», медалями: «Партизану Вітчизняної війни 1 ступеня» (1944), «За бойові заслуги» (1.02.1945), «За перемогу над Німеччиною у Великій вітчизняній війні 1941 - 1945 рр.» (9.05.1945), «30 років Радянської армії і флоту», «Заслужений працівник НКВС» (6.11.1943). Звільнений в запас з військової служби (08.08.1954). Працював начальником I спецвіділу Міністерства вищого і середньо спеціальної освіти УРСР. 
В июле месяце 1944 года, в период массового отступления немецких войск на запад, весь аппарат окружного отдела «СД» из Дрогобыча эвакуировался в город Краков.

По тем же данным, первоначально шефом «СД» является гауптштурмфюрер ТОЛЛЕ Николаус, который руководил аппаратом «СД» до августа 1942 года, затем был переведен в гор. Львов на должность замистителя начальника «СД». Вместо него был назначен гауптштурмфюрер ВЕНЦЕЛЬ, который возглавлял Дрогобычское «СД» до весны 1943 года, а затем по неизвестным обстоятельствам с работы был снят и выехал в Восточную Пруссию. На его место заступил штурмбанфюрер БЛОК Иоганс, возглавлявший «СД» в гор. Дрогобыче до изгнания немецких оккупантов.

БЛОК Иоганс в начале 1947 года арестован в гор. Вена /Австрия/ отделом инспекции Советской части Союзнической Комиссии по Австрии, о чем нами ориентировано 2-ое Управление МГБ УССР запиской по «ВЧ» № 163 от 7 февраля 1947 года.

«СД» в гор. Дрогобыче имело следующие отделы:

а) Отдел по делам евреев, возглавлял этот отдел штурмпарфюрер ГАБРИИЛЬ;

б) Второй отдел - по делам немцев, фольксдойчей и райхсдойчей, начальником отдела является ХИРТШУЛЬЦ;

в) Отдел по польским делам, возглавлял штурмшарфюрер МЮЛЛЕР;

г) Украинский отдел, возглавлял также ХИРТШУЛЬЦ;

д) Отдел контроля лагерей военнопленных, начальник отдела гауптшарфюрер КРАУЗЕ Гельмут;

е) Пограничный отдел, начальник отдела КРАУЗЕ Гельмут и ГИНТЕР Карл;

ж) Отдел контроля тюрем, начальник отдела БЕР;

3) 7-й оперативный отдел, начальник отдела штурмпарфюрер - МАРЦИНОВСКИ;

и) Административно-хозяйственный отдел, начальник отдела обершарфюрер - ШЕНКЕЛЬ Карл;

к) Отдел учета, начальник отдела обершарфюрер ШОЛЬТЕН.

Помимо этого имелись отделения «СД» в г.г. Самборе, Бориславе, Ходорове, и Долине (Станиславской области), которые о своей работе отчитывались перед окружным отделом «СД» в гор. Дрогобыче.

Начальнику Дрогобычского «СД» также персонально подчинялись:

1. Криминальные комиссариаты г.г. Дрогобыча, Самбора, Стрия с филиалами гор гор. Борислава, Турка и Сколе.

2. Немецкая жандармерия.

3. Украинская полиция.

4. Вспомогательная украинская полиция.

5. Шуцполиция.

В функции «СД» входило:

а) Борьба с партизанским движением.

б) Выявление и репрессия партийно-советского актива;

в) Выявление и уничтожение еврейского населения;

д) Борьба с агентурой советских разведывательных ы контрразведывательных органов;

г) Борьба с саботажем в промышленности, спекуляцией, учетом иностранно-подданных, цензура и т.п.

Для этой цели аппарат «СД» проводил на территории области большую работу по насаждению своей агентуры во всех отраслях промышленности, торговли, учреждениях, среди неорганизованного населения, духовенства и сельском хозяйстве.

Из числа официальных сотрудников Дрогобычского аппарата «СД»:

арестовано 6 человек

объявлено в розыск 19 человек.

Из числа агентуры Дрогобычского «СД»:

Арестовано 114 человек

Объявлено в розыск 9 человек. 
Разрабатываються:

По оперативным учетам 39 человек, в том числе:

По делам-формулярам - 30

По агентурным делам - 9

По литерному делу «СД» работает агентурно-осведомительный аппарат в количистве 6 человек, из них:

Агентов - 1

Осведомитилей -5

При этом прилагаются списки выявленных официальных сотрудников «СД» и их агентуры. ПРИЛОЖЕНИЕ: По тексту на «24» листках.-

ЗАМ НАЧАЛЬНИКА 3 ОТД 2 ОТДЕЛА УМГБ ДРОГ. ОБЛ.

Лейтенант. - /РУДЬ $\%$

«СОГЛАСЕН»

И.О. НАЧАЛЬНИКА 2 ОТДЕЛА УМГБ ДРОГ ОБЛАСТИ

Майор /ПРОНИН 7

«5» марта 1947 года.

г. Дрогобыч.

Галузевий державний архів Служби безпеки України (ГДА СБУ). - Ф. 1. - On. 96 (1954). Спр. 12. - Арк. 73-74зв.

\section{СПИСОК ВИКОРИСТАНИХ ДЖЕРЕЛ І ЛІТЕРАТУРИ}

1. Архіви окупації. 1941 - 1944 / Упоряд. Н. Маковська. - К.: Видавничий дім «Києво-Могилянська академія», 2006. $-872 \mathrm{c}$.

2. Вільне слово. - 1941. - № 60. - 24 листопада. - С. 4.

3. Гладилович А. «Кличе Україна, наша Батьківщина» / А. Гладилович // Дрогобиччина - земля Іван Франка: Збірник географічних, історичних, етнографічно-побутових матеріалів та мемуарів. - Т. 4. - Дрогобич: «Відродження», 1997. - С. 362-371.

4. Державний архів Львівської області (далі - ДАЛО). - Ф. Р-1928. - Ф. 1. - Спр. 2.

5. ДАЛО. - Ф. Р-1928. - Ф. 1. - Спр. 3.

6. ДАЛО. - Ф. Р-1928. - Ф. 1. - Спр. 4.

7. ДАЛО. - Ф. Р-1942. - Ф. 1. - Оп. 1. - Спр. 2.

8. Ільницький В. Документи до історії нацистських органів безпеки у Дрогобичі $(1941-1944)$ / В. Ільницький // Дрогобицький краєзнавчий збірник / [гол. ред. Л. Тимошенко, упоряд. і наук. ред. М. Галів, В. Ільницький, В. Футала]. - Спецвипуск ІІІ. - Дрогобич: Посвіт, 2017. - С. 393-421.

9. Мороз В. Українська Народна Самооборона (УНС) на терені Дрогобицької області (1943 рік) / В. Мороз // Визвольний шлях. - 2000. - Кн. 6. - С. 54-72.

10. Нариси з історії Дрогобича (від найдавніших часів до початку XXI ст.) / Наук. ред. Л. Тимошенко. Дрогобич: Коло, 2009. - 320 с.

11. Паньківський К. Роки німецької окупації / К. Паньківський. - Нью-Йорк - Торонто, 1965. - 480 с.

12. Центральний державний архів вищих органів влади України. - Ф. 3836. - Оп. 1. - Спр. 66.

13. Чуев С. Г. Спецслужбы третьего рейха / С. Г. Чуев. - СПб.: «Нева»; М.: ОЛМА-ПРЕСС Образование, 2003. $-448 \mathrm{c}$.

${ }^{6}$ Рудь Олексій Федотович (1911 - ?). Українець. Освіта середня. Лейтенант, старший лейтенант. Член партії (1942), на чекістській роботі з 1942 р. Старший оперуповноважений 10 відділення 2 відділу УМДБ Дрогобицької області. Заступник начальника 3 відділення (боротьба 3 агентурою німецької розвідки) 2 відділу УМДБ Дрогобицької області (зг. 01.1947). Заступник начальника 4 відділення 2 відділу УМДБ Дрогобицької області (зг. 01.1948). Заступник начальника 1 відділення 2-Н УМДБ Дрогобицької області (зг. 12.1950).

${ }^{7}$ Пронін Олександр Іванович (1909 - ?). Українець. Освіта неповна середня. Майор. Член партії (1936), на чекістській роботі з 1934 р. Начальник 2 відділу УМДБ Дрогобицької області. Заступник начальника 2 відділу (контррозвідувальний) УМДБ Дрогобицької області (зг. 01.1947). Заступник начальника Самбірського МВ УМДБ Дрогобицької області (зг. 01.1948). 
14. Яців В. Дрогобич - місто нафтового басейну у воєнних роках 1939 - 44 / В. Яців // Дрогобиччина земля Івана Франка. - Т. 3. - Нью-Йорк - Париж - Сидней - Торонто, 1986. - С. 87-98.

15. Budzyński W. Miasto Schulza / W. Budzyński. - Warszawa, 2005. - $453 \mathrm{~s}$.

16. Winiarski M. Gdy Schulz spotkal śmierś w Drohobyczu / M. Winiarski // Ziemia Drohobycka. - 1998. Nr. 11. cz. 1. - S. 37-44.

\section{REFERENCES}

1. Arkhivy okupatsii. 1941 - 1944 / Uporiad. N. Makovska. - K.: Vydavnychyi dim «Kyievo-Mohylianska akademiia», 2006. $-872 \mathrm{~s}$.

2. Vilne slovo. - 1941. - № 60. - 24 lystopada. - S. 4.

3. Hladylovych A. «Klyche Ukraina, nasha Batkivshchyna» / A. Hladylovych // Drohobychchyna - zemlia Ivan Franka: Zbirnyk heohrafichnykh, istorychnykh, etnohrafichno-pobutovykh materialiv ta memuariv. - T. 4. Drohobych: «Vidrodzhennia», 1997. - S. 362-371.

4. Derzhavnyi arkhiv Lvivskoi oblasti (dali-DALO). - F. R-1928. - F. 1. - Spr. 2.

5. DALO. - F. R-1928. - F. 1. - Spr. 3.

6. DALO. - F. R-1928. - F. 1. - Spr. 4.

7. DALO. - F. R-1942. - Op. 1. - Spr. 2.

8. Ilnytskyi V. Dokumenty do istorii natsystskykh orhaniv bezpeky u Drohobychi $(1941-1944)$ / V. Ilnytskyi // Drohobytskyi kraieznavchyi zbirnyk / [hol. red. L. Tymoshenko, uporiad. i nauk. red. M. Haliv, V. Ilnytskyi, V. Futala]. - Spetsvypusk III. - Drohobych: Posvit, 2017. - S. 393-421.

9. Moroz V. Ukrainska Narodna Samooborona (UNS) na tereni Drohobytskoi oblasti (1943 rik) / V. Moroz // Vyzvolnyi shliakh. -2000 . - Kn. 6. - S. 54-72.

10. Narysy z istorii Drohobycha (vid naidavnishykh chasiv do pochatku KhKhI st.) / Nauk. red. L. Tymoshenko.Drohobych: Kolo, 2009. - 320 s.

11. Pankivskyi K. Roky nimetskoi okupatsii / K. Pankivskyi. - Niu-York - Toronto, 1965. - $480 \mathrm{~s}$.

12. Tsentralnyi derzhavnyi arkhiv vyshchykh orhaniv vlady Ukrainy. - F. 3836. - Op. 1. - Spr. 66.

13. Chuev S. H. Spetssluzhby treteho reikha / S. H. Chuev. - SPb.: «Neva»; M.: OLMA-PRESS Obrazovanye, 2003. $-448 \mathrm{~s}$.

14. Yatsiv V. Drohobych - misto naftovoho baseinu u voiennykh rokakh 1939-44 / V. Yatsiv // Drohobychchynazemlia Ivana Franka. - T. 3. - Niu-York - Paryzh - Sydnei - Toronto, 1986. - S. 87-98.

15. Budzyński W. Miasto Schulza / W. Budzyński. - Warszawa, 2005. - 453 s.

16. Winiarski M. Gdy Schulz spotkal śmierś w Drohobyczu / M. Winiarski // Ziemia Drohobycka. - 1998. Nr. 11. cz. 1. - S. 37-44.

Стаття надійшла до редакиії 23.06.2017 p. 